\author{
Małgorzata E. Szymańska \\ Maria Curie-Skłodowska University in Lublin, Poland \\ ORCID: 0000-0001-5976-496X \\ malgorzata.szymanska@umcs.pl
}

\title{
Protection of Biosphere Resources in Plant Production
}

\author{
Ochrona zasobów biosfery w produkcji roślinnej
}

\author{
SUMMARY
}

The article analyzes the impact of plant production on the protection of biosphere resources. Agriculture significantly affects the quality of resources and natural environment assets and shapes their character. The quality of environmental resources determines the size and directions of agricultural production, and agriculture changes ecosystems, shapes the landscape, affects the quality and quantity of natural resources. European integration has influenced the relationship between agriculture and the environment in many directions. EU legislation and the formulation of development strategies and economic programs contribute to the greening of agricultural land use and the protection of biosphere resources. The assessment of these activities is definitely positive due to the creation of conditions for conflict-free coexistence of the protective function and the agricultural function.

Keywords: agriculture; biosphere; crop production; natural resources; agricultural activity

Biodiversity is a natural capital on which the quality of social and economic development of each country depends. Human activity and related economic expansion strongly reduce the diversity of the environment, especially the natural one. Reports from relevant UN agencies and other international organizations show that as a result of this activity, dozens and hundreds of species of birds, insects, amphibians and plants as well as other elements of nature disappear from the surface of our globe every year. The conversion of primary or natural ecosystems into arable land and the intensification of agricultural production have led to the impoverishment of biodiversity in global nature resources, including Poland. The loss of biodiversity and ecosystem services is seen as one of the biggest existen- 
tial threats in the world ${ }^{1}$. The complex mutual relations of society and nature is one of the most important and most current ecological and sociological problems of modern times. Protecting living natural resources has become a challenge. Its solution should be based on learning the general principles of the biosphere and the principles of economic globalization. The multidimensional interdependence of agricultural activities and the protection of biosphere resources are currently recognized and taken into account in the objectives and instruments of the European Union's common agricultural policy. The natural environment of rural areas is subject to various impacts with the intensification of agricultural production, which may lead to a loss of biological diversity and landscape values ${ }^{2}$.

Pursuant to Article 2 (1) of the Act of 16 April 2004 on Nature Protection ${ }^{3}$, the primary task of nature protection is to care for the preservation and sustainable use of natural resources. According to the doctrine's position, it is an example of a conservative aspect of environmental protection, which consists in protecting specific elements or values of the environment against destruction or degradation ${ }^{4}$. In the content of Article 3 (1) ANP the obligation to include nature protection requirements in business and investment activities has been defined ${ }^{5}$.

The intensification of agriculture significantly limits the protection of biosphere resources, although in accordance with Article 4 of the Act of 27 April 2004 Environmental Protection $\mathrm{Law}^{6}$ conducting agricultural activity in the field of plant production is simply using the environment. Plant production is necessary for human existence to produce food of plant and animal origin. Care for rural biodiversity, water availability, soil structure and climate stability in agricultural activities is subject to many legal regulations. This is due to the need to combine environmental protection objectives and the sustainable development of agriculture. The variety of legal regulations regarding the protection of the biosphere in plant production makes it necessary to know the legal norms arising from the provisions of the Act of 3 February 1995 on the Protection of Agricultural and Forestry Land ${ }^{7}$, Act of 10 July 2007 on Fertilizers and Fertilization ${ }^{8}$, Act of 8 March 2013 on Plant

1 Resolution No. 213 of the Council of Ministers of 6 November 2015 regarding the approval of the "Protection Program and sustainable use of biodiversity with the Action Plan 2015-2020" (M.P. item 1207).

2 A. Habuda, Koncepcje ochrony przyrody w prawie polskim i wspólnotowym, [in:] Wspólnotowe prawo ochrony środowiska i jego implementacja w Polsce trzy lata po akcesji, red. J. Jendrośka, M. Bar, Wrocław 2008, p. 128.

3 Journal of Laws 2018, item 1614 as amended, hereinafter: ANP.

4 R. Paczuski, Prawo ochrony środowiska, Bydgoszcz 2000, p. 438.

5 M.A. Król, Dobre praktyki w rolnictwie jako przejaw realizacji zasady zrównoważonego rozwoju, „Przegląd Prawa Ochrony Środowiska” 2010, nr 1, p. 54.

6 Journal of Laws 2019, item 1396.

7 Journal of Laws 2017, item 1161.

8 Journal of Laws 2018, item 1259. 
Protection Products 9 , or the Act of 22 June 2001 on Microorganisms and Genetically Modified Organisms ${ }^{10}$. As part of agricultural activities, the agricultural sector has an impact on the natural environment, in particular on the agrochemical state and physical properties of soil, water and air. This causes that the specifics of agriculture are the side effects of agricultural activities, which can be either positive or negative environmental effects.

Agricultural activities in the field of plant production affect the condition of existing ecosystems, affect water relations, climate, spatial development of the country and the cultural landscape. It may also perform certain pro-ecological functions, increasingly recognized as the delivery of public goods. The protection of biosphere resources is an example of such a good ${ }^{11}$.

The condition of effective implementation of pro-environmental functions by agriculture is the implementation of the principle of sustainable development, hence at the decision-making levels of the bodies of the European Union and the Member States new agricultural policy development strategies are adopted, which aim to shape such a model of agriculture in which there is harmony between production needs and market criteria and its other functions, including those related to the provision of environmental public goods ${ }^{12}$.

The volume of agricultural production depends on natural conditions and the socio-economic development of the country. In Poland, changes in the structure of agricultural production were mainly caused by instruments of the common agricultural policy. According to the rules of cross compliance in plant production for the preservation of biosphere resources, multi-species crop rotation has a positive effect on soil fertility and fertility, reduces the risk of mass occurrence of pests and weeds. Soil quality and agricultural usefulness are the basic factors conditioning plant production and affecting its profitability. Soils are also an element conditioning a given type of landscape, which affects the way the area is used. Crop rotation favoring the conservation of biosphere resources should consist of alternating spring and winter plants, annual and perennial, cultivated in a compact crop and in wide rows, as well as characterized by a variety of varieties, a mixture of species, sown crops and catch crops. Appropriate selection of crop species and varieties can be increased by genetic diversity of varieties, cultivating old local genotypes alongside modern, high-yielding varieties. The most appropriate method of protecting crop

9 Journal of Laws 2019, item 1900.

10 Journal of Laws 2019, item 706.

${ }^{11}$ M. Szymańska, Zasada zrównoważonego rozwoju rolnictwa $w$ świetle uregulowań gałęzi prawa i polityki rolnej, „Studia Iuridica Lublinensia” 2016, nr 1, DOI: http://dx.doi.org/10.17951/ sil.2016.25.1.121, p. 124.

12 J. Wilkin, Wielofunkcyjność rolnictwa - nowe ujęcie roli rolnictwa $w$ gospodarce $i$ społeczeństwie, [in:] Wielofunkcyjność rolnictwa. Kierunki badań, podstawy metodologiczne i implikacje praktyczne, red. J. Wilkin, Warszawa 2010, p. 25. 
plant genetic resources is to preserve them in situ (i.e. where they occur naturally) - in regions closely related to their origin. Cultivation of forgotten and relict plant species, such as calder, radish, spelled, ewe, millet, rough oats and lentils contribute to the protection of biodiversity. The occurrence and maintenance of field weeds in a non-threatening condition for crops and crops, using their protective, herbal, honey, habitat and nutritional properties is one of the instruments implementing environmental protection under the common agricultural policy ${ }^{13}$.

Landscaping and appropriate ecological infrastructure around agricultural land is also very important in the protection of biosphere resources and depends not only on habitat conditions and farming practices but also on the diversity of the surrounding landscape. This diversity is achieved by maintaining or introducing mid-field tree stands, rows of trees, avenues of trees, scrubs, stonework and hedges around the land. The protection of peat bogs, wetlands, ponds, copper and other non-agricultural sites in plant production also has a positive effect on the protection of biosphere resources. These habitats serve as a place to live, develop, shelter and obtain food for many useful animal species, including pollinators and natural enemies of pests.

The large-scale use of chemical plant protection products is not indifferent to the living world. The main threats to soil fertility include: decrease in soil organic matter content, floods and mass soil movements, sealing, erosion processes, pollution from local and diffuse sources, compaction, decrease in biodiversity and salinity. One of the principles of traditional agriculture was crop rotation, which will probably fall back when coming to extensive agricultural production. Currently, $70 \%$ of crops in Poland are cereals, often monocultures, which is why diversification of crops is sought under the common agricultural policy ${ }^{14}$.

In Poland, too many cereals, root crops and maize are grown, which adversely affects the chemical composition of the soil. As part of direct payments, agricultural producers cultivating legumes and legumes thanks to which the level of organic matter increases in the soil receive additional financial resources. Initiating farmers' conscious actions to improve the environment and biodiversity of rural areas has a positive effect on the protection of biosphere resources.

Widespread chemisation of agriculture has a negative impact on agricultural ecosystems. Over the past 60 years, organic matter in the soil structure has fallen by as much as $40 \%$. The main reasons for the drop in the quality of arable soils are: their intensive exploitation, abandoning the use of natural fertilizers (especially manure) in favor of mineral ones, as well as widespread use of plant protection

${ }^{13}$ M.A. Król, Producent rolny jako podmiot korzystająy ze środowiska, „Studia Iuridica Agraria” 2013, t. 7, p. 280.

${ }^{14}$ B. Jeżyńska, Znaczenie i funkcjonowanie zasady cross-compliance $w$ systemie rolniczych dopłat bezpośrednich, „Studia Iuridica Lublinensia” 2010, t. 13, pp. 35-50. 
products. In addition to incorrect (excessive) fertilization, causing deep changes in the soil environment, the most important threat from a natural point of view to the protection of biosphere resources is the widespread use of plant protection products, in particular herbicides. As part of the development of agricultural culture, specific biocoenoses developed in rural areas, whose plants occurring in segetal communities have long been considered as an undesirable element. Perceived as a competition of arable crops, they were eliminated from cultivation. Horticulture, weeding and purification of seeds were to ensure the advantage of arable crops over the accompanying segetal plants. The widespread use of herbicides has put a large group of segetal plants under threat today. These species, which make up the full range of biodiversity in agricultural areas, are significant from an environmental point of view. They decorate the fields, affecting the attractiveness of the landscape (e.g. poppies), but are also important for maintaining other elements of agricultural biocoenoses, in particular insects and birds ${ }^{15}$.

Water is an important element of biosphere resources in plant production. The main purpose of Directive 2000/60/EC of the European Parliament and of the Council of 23 October 2000 establishing a framework for Community action in the field of water policy, called the Water Framework Directive (WFD), is to achieve good status for waters and terrestrial ecosystems which depend on them (Article 4). Member States were required to achieve the above target by 2015, and in justified cases the achievement of the target was extended to 2021 or 2027. Pursuant to the Act of 20 July 2017 - Water Law ${ }^{16}$ adopted in Poland, the National Water Holding is responsible for the implementation of the Water Framework Directive. Among the measures set out in the water and environmental program of the country, referring to rural areas, were in particular limiting the outflow of nitrates to waters from agricultural areas. The main cause of area pollution affecting Community waters is most often surface and subsurface runoff of nitrates from agricultural areas. In view of the above, the Council Directive of 12 December 1991 concerning the protection of waters against pollution caused by nitrates from agricultural sources (91/676/EEC), called the Nitrates Directive, was adopted. Pursuant to the Directive, EU Member States, in order to reduce water pollution by nitrates from agricultural sources and prevent further pollution, designate waters that are polluted or threatened with pollution, as well as danger zones from which flows into these waters take place. In designating them, Member States are guided by the criteria set out in Annex I to the Nitrates Directive. Therefore, they determine whether nitrogen compounds in waters do not exceed the limit values or do not

${ }^{15}$ M. Szymańska, Ochrona środowiska naturalnego w systemie wsparcia bezpośredniego, [in:] Pro Scientia Iuridica, red. M. Chrzanowski, A. Przyborowska-Klimczak, P. Sendecki, Lublin 2014, pp. 335-344.

16 Journal of Laws 2018, item 2268 as amended. 
show an upward tendency to exceed them if no remedial action is taken. The content of nitrogen compounds must not exceed: in fresh surface waters intended for drinking water $-50 \mathrm{mg} \mathrm{NO}_{3} / 1$; in groundwater: nitrates $-50 \mathrm{mg} \mathrm{NO}_{3} / 1$, in addition in surface waters - values of parameters indicating eutrophication or a tendency to eutrophication of waters. Member States shall establish a set of principles of good agricultural practice for voluntary compliance and introduce action programs setting out mandatory countermeasures to be used for designated vulnerable zones. When a Member State applies mandatory remedies throughout the country, it is exempted from the obligation to define risk zones. The Nitrates Directive is implemented in four-year cycles, and the results of the evaluation of the effectiveness of action programs are reported to the European Commission.

Agricultural activity is a collection of closely functioning components in which a change in one of them causes a change in its other elements. To ensure the protection of biosphere resources in agricultural production, principles of good agricultural practice are developed. In 2019, the Minister of Agriculture and Rural Development adopted a set of recommendations for good agricultural practice, which replaces the Abbreviated set of principles of good agricultural practice for the purposes of implementing the Nitrates Directive, which is part of the Code of Good Agricultural Practice of 2004, and other requirements of this Code relating to rules for the use of nitrogen-containing fertilizers and soil liming, storage of natural fertilizers. The set of recommendations specifies periods when the agricultural use of fertilizer is inappropriate and the circumstances and methods of agricultural use of fertilizer: in areas with a high slope; on land saturated with water, flooded, frozen or covered with snow; near watercourses. The Good Agricultural Practice Guidelines also contain information on the appropriate capacity and construction of animal manure storage containers, doses and uniformity of application, both mineral and natural fertilizers, which ensure that nutrient losses to waters are maintained at an acceptable level. A number of actions have been implemented to protect the biosphere resources in plant production. The main programs of impact on agriculture in the field of plant production include supporting activities in less-favored areas, supporting agri-environment-climate projects ${ }^{17}$.

To sum up, agriculture, which covers such a large area of the country and operates in close proximity to other ecological systems, e.g. forests, peat bogs or water reservoirs, must fulfill the functions of environmental protection ${ }^{18}$. The legal instruments presented indicate actions undertaken in this direction. It is necessary

${ }_{17}$ Ministerstwo Rolnictwa i Rozwoju Wsi, Zbiór zaleceń dobrej praktyki rolniczej do dobrowolnego stosowania, www.gov.pl/web/rolnictwo/zbior-zalecen-dobrej-praktyki-rolniczej-do-dobrowolnego-stosowania [access: 10.02.2020].

${ }_{18}$ M.A. Król, Wybrane zagadnienia ochrony biosfery, [in:] Prawo administracyjne materialne, red. M. Stahl, Warszawa 2016, p. 767. 
to further improve the awareness of existing threats resulting from the loss of biodiversity and a comprehensive impact on increasing the responsibility of agricultural producers for the state of ecosystems in which they operate. Farmers should know how to serve and manage the resources they use for production. Production of food that meets high health standards is important, but also pro-environmental production methods that guarantee the preservation of biological resources for future generations. Rapid changes that have taken place in recent years, which are associated with the impoverishment of biodiversity, including the disappearance of fragmented cropping area, drainage of wetlands, cutting of field afforestation, results in a significant reduction in the diversity of vertebrates inhabiting these areas. Under agri-environmental programs, subsidies can be applied for in exchange for protecting the most sensitive bird species living in wetlands, while also protecting other species that inhabit these areas. It is also good practice, especially on large areas of meadows, natural cattle grazing within land communities, formerly often practiced. It is necessary to preserve mid-field tree stands, and in places where they are lacking - to restore them. This increases the biodiversity in the agricultural landscape, and at the same time protects the fields against soil erosion and results in a reduction of crop pests by eliminating them through the birds inhabiting these enclaves. A further radical change in European agriculture is announced by the New Green Deal adopted at the end of 2019.

\section{REFERENCES}

\section{Literature}

Habuda A., Koncepcje ochrony przyrody w prawie polskim i wspólnotowym, [in:] Wspólnotowe prawo ochrony środowiska i jego implementacja w Polsce trzy lata po akcesji, red. J. Jendrośka, M. Bar, Wrocław 2008.

Jeżyńska B., Znaczenie i funkcjonowanie zasady cross-compliance $w$ systemie rolniczych dopłat bezpośrednich, „Studia Iuridica Lublinensia” 2010, t. 13.

Król M.A., Dobre praktyki w rolnictwie jako przejaw realizacji zasady zrównoważonego rozwoju, „Przegląd Prawa Ochrony Środowiska” 2010, nr 1.

Król M.A., Producent rolny jako podmiot korzystajacy ze środowiska, „Studia Iuridica Agraria” 2013, t. 7.

Król M.A., Wybrane zagadnienia ochrony biosfery, [in:] Prawo administracyjne materialne, red. M. Stahl, Warszawa 2016.

Ministerstwo Rolnictwa i Rozwoju Wsi, Zbiór zaleceń dobrej praktyki rolniczej do dobrowolnego stosowania, www.gov.pl/web/rolnictwo/zbior-zalecen-dobrej-praktyki-rolniczej-do-dobrowolnego-stosowania [access: 10.02.2020].

Paczuski R., Prawo ochrony środowiska, Bydgoszcz 2000.

Szymańska M.E., Ochrona środowiska naturalnego w systemie wsparcia bezpośredniego, [in:] Pro Scientia Iuridica, red. M. Chrzanowski, A. Przyborowska-Klimczak, P. Sendecki, Lublin 2014. 
Szymańska M.E., Zasada zrównoważonego rozwoju rolnictwa $w$ świetle uregulowań gałęzi prawa i polityki rolnej, „Studia Iuridica Lublinensia” 2016, nr 1,

DOI: http://dx.doi.org/10.17951/sil.2016.25.1.121.

Wilkin J., Wielofunkcyjność rolnictwa - nowe ujęcie roli rolnictwa w gospodarce i społeczeństwie, [in:] Wielofunkcyjność rolnictwa. Kierunki badań, podstawy metodologiczne i implikacje praktyczne, red. J. Wilkin, Warszawa 2010.

\section{Legal acts}

Act of 3 February 1995 on the Protection of Agricultural and Forestry Land (Journal of Laws 2017, item 1161).

Act of 22 June 2001 on Microorganisms and Genetically Modified Organisms (Journal of Laws 2019, item 706).

Act of 16 April 2004 on Nature Protection (Journal of Laws 2018, item 1614 as amended).

Act of 27 April 2004 Environmental Protection Law (Journal of Laws 2019, item 1396).

Act of 10 July 2007 on Fertilizers and Fertilization (Journal of Laws 2018, item 1259).

Act of 8 March 2013 on Plant Protection Products (Journal of Laws 2019, item 1900).

Act of 20 July 2017 - Water Law (Journal of Laws 2018, item 2268 as amended).

Resolution No. 213 of the Council of Ministers of 6 November 2015 regarding the approval of the "Protection Program and sustainable use of biodiversity with the Action Plan 2015-2020" (M.P. item 1207).

\section{STRESZCZENIE}

Artykuł zawiera analizę wpływu produkcji roślinnej na ochronę zasobów biosfery. Rolnictwo w istotny sposób wpływa na jakość zasobów i walorów środowiska przyrodniczego oraz kształtuje ich charakter. Jakość zasobów środowiskowych determinuje wielkość i kierunki produkcji rolniczej, a gospodarka rolna zmienia ekosystemy, kształtuje krajobraz, wpływa na jakość i ilość zasobów naturalnych. Integracja europejska wielokierunkowo wpłynęła na relację rolnictwo - środowisko. Legislacja unijna oraz konstruowanie strategii rozwojowych i programów gospodarczych przyczyniają się do ekologizacji użytkowania gruntów rolnych i ochrony zasobów biosfery. Ocena tych działań jest zdecydowanie pozytywna ze względu na tworzenie warunków do bezkonfliktowego współistnienia funkcji ochronnej i funkcji rolniczej.

Slowa kluczowe: rolnictwo; biosfera; produkcja roślinna; zasoby naturalne; działalność rolnicza 